Original Article

\title{
Fatty acid profile variations after exposure to textile industry effluents in Indian Major Carps
}

\author{
Variações do perfil de ácidos graxos após exposição a efluentes da indústria têxtil nas \\ principais carpas indianas
}

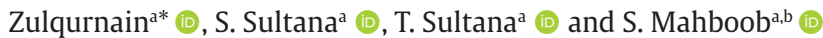 \\ ${ }^{a}$ Government College University, Department of Zoology, Faisalabad, Pakistan \\ 'King Saud University, College of Science, Department of Zoology, Riyadh, Saudi Arabia
}

\begin{abstract}
Indian major carps are the widely consumed fish species of Pakistan, being a cheap source of proteins and unsaturated fatty acids, they are good for cardiovascular health. Water pollution due to discharge of untreated industrial waste water into water bodies contaminates this precious source of nutrients. The present study therefore, was aimed to assess deterioration of fatty acid profile of three Indian major carp species due to different concentrations of industrial wastes. The water samples were collected from the river Chenab at the site where it receives industrial wastewater via Chakbandi drain. After exposure to $1.5 \%, 3.0 \%$, and $4.5 \%$ dilutions of collected water in different aquaria it was observed that proportion of unsaturated fatty acids in selected fish species were decreased significantly as the intensity of the dose increased $(\mathrm{P}<0.05)$. Conversely the level of saturated fatty acids increased with the increasing dose of treatment $(\mathrm{P}<0.05)$. These findings suggest that untreated wastewater not only deteriorate the fatty acid profile of aquatic animals but also these toxic substances can reach human body through fish meat and pose further health hazards. Therefore, it is highly recommended that industrial effluents should be treated before they are dumped into water bodies.
\end{abstract}

Keywords: textile effluents, bio indicator, pollution, major carps, fatty acid.

\begin{abstract}
Resumo
As carpas indianas são as espécies de peixes mais consumidas no Paquistão, sendo uma fonte barata de proteínas e de ácidos graxos insaturados e boa para a saúde cardiovascular. A poluição da água por causa do descarte de resíduos industriais não tratados em corpos d'água contamina essa preciosa fonte de nutrientes. Portanto, o presente estudo teve como objetivo avaliar a deterioração do perfil de ácidos graxos de três principais espécies de carpas indianas em diferentes concentrações de resíduos industriais. As amostras de água foram coletadas do rio Chenab no local onde recebe esgoto industrial via dreno de Chakbandi. Após a exposição a diluições de 1,5\%, 3\% e 4,5\% da água coletada em diferentes aquários, foi observado que a proporção de ácidos graxos insaturados em espécies de peixes selecionadas diminuiu significativamente com o aumento da intensidade da dose $(P<0,05)$. Por outro lado, o nível de ácidos graxos saturados aumentou com a elevação da dose de tratamento $(\mathrm{P}<0,05)$. Essas descobertas sugerem que águas residuais não tratadas não apenas deterioram o perfil de ácidos graxos dos animais aquáticos, mas também essas substâncias tóxicas podem atingir o corpo humano por meio da carne de peixe e representar mais riscos à saúde. Portanto, é recomendável que os efluentes industriais sejam tratados antes de serem despejados em corpos d'água.
\end{abstract}

Palavras-chave: efluentes têxteis, bioindicador, poluição, carpas principais, ácido graxo.

\section{Introduction}

Indian major carp species, Labeo rohita (Ham.), Catla catla (Ham.), and Cirrhinus mrigala (Ham.) having great economic importance are the commercial fish species and important aquatic food item of Pakistan due to consumer prefer ability owing to their taste and quality of meat (Hussain et al., 2018).
In the recent past, fish culture has increased in Asian countries (Hussain et al., 2018). Fish has a highly nutritional Value like rich source of protein and omega 3 Fatty acid. Poly unsaturated omega-3 prevent cardio vascular effect like blood viscosity reduced, platelet inhibiting, Blood viscosity lower, inflammation suppression, Function of

*zulfi.gujjar@gmail.com

Received: July 14, 2021 - Accepted: September 16, 2021

This is an Open Access article distributed under the terms of the Creative Commons Attribution License, which permits unrestricted use, distribution, and reproduction in any medium, provided the original work is properly cited. 
blood vessels improve and resistance of insulin. If fish intake increased so the risk of CVD may lead to decrease (Rhee et al., 2017).

Fish nutrients play a positive role in human health. The n-3 LC PUFA in fish have also a stabilized amino acid configuration, carry a more value of calcium minerals, taurine and vitamins D3, choline, B12, selenium, phosphorus and iodine. Moreover, fish as well contribute important proportion of iron, zinc and vitamin A to a population (Lund et al., 2013).

Municipal wastewater and unprocessed industrial direct discharge into drains, rivers on canals actually the aggravate of water pollution. Furthermore, big concentration of many pollutants may rise $\mathrm{pH}$, total dissolved solids (TDS), biological oxygen demand (BOD), total suspended solids (TSS), electrical conductivity (EC), metals like as $\mathrm{Cr}, \mathrm{Cd}$, $\mathrm{Ni}$ and fecal coliform, $\mathrm{Pb}$ therefore making such water toxic for irrigation and domestic use (Tariq et al., 2020). This untreated water has proved to be detrimental for human consumption.

In Pakistan and other developing countries with minimal resources and infrastructure, industrial wastes are treated malfunctionally because of inadequacy of waste treatment machinery. It has been reported that only the smallest amount of waste $(<8 \%)$ is treated efficiently while the majority of the industrial drainage goes untreated into the rivers, streams and canals, violating the directions of environmental protection agencies (Ensink et al., 2004).

Multiple researches have established a link between raised toxicant levels in water bodies and bioaccumulation in aquatic life forms, the fish gills, liver and muscle tissues primarily involved (Lv et al., 2019). The higher concentrations of heavy metals in edible part of the fish are an additional threat to human health (Chaudhry and Jabeen, 2011).

The aim of present study was to assess perturbed fatty acid profiles in Indian major carps after treatment with different concentrations of industrial effluents as a potential bio-indicator of water pollution.

\section{Materials and Methods}

\subsection{Study area}

Water samples were collected from the River Chenab where it receives wastewater from the Chakbandi drain at latitude $31.570^{\circ}$ and longitude $72.534^{\circ}$. The Chakbandi drain collects wastewater from different industries and pours these industrial wastes into River Chenab (Figure 1). The water samples were analyzed for $\mathrm{pH}$, total dissolved solids (TDS), salinity, alkalinity, electric conductivity (EC), hardness, dissolved oxygen (DO), $\mathrm{CO}_{2}$ and Temperature (Table 1). Water samples from upstream of the site was used as control. Fish with average weight 10 grams, total length $9.0 \mathrm{~cm}$ and fork length $7.0 \mathrm{~cm}$ were collected from Satyana Road Fish Hatchery, Faisalabad and were acclimatized in cemented tanks $10 \times 5 \mathrm{ft}$ for 2 week. During acclimatization period fish were maintained on feeding regime of $25 \%$ protein feed 2 times a day. Effluent treatment in concentrations of $5 \%, 7.5 \%$ and $10 \%$ for Labeo rohita (Ham.), Catla catla (Ham.) and Cirrhinus mrigalae (Ham.) for 96

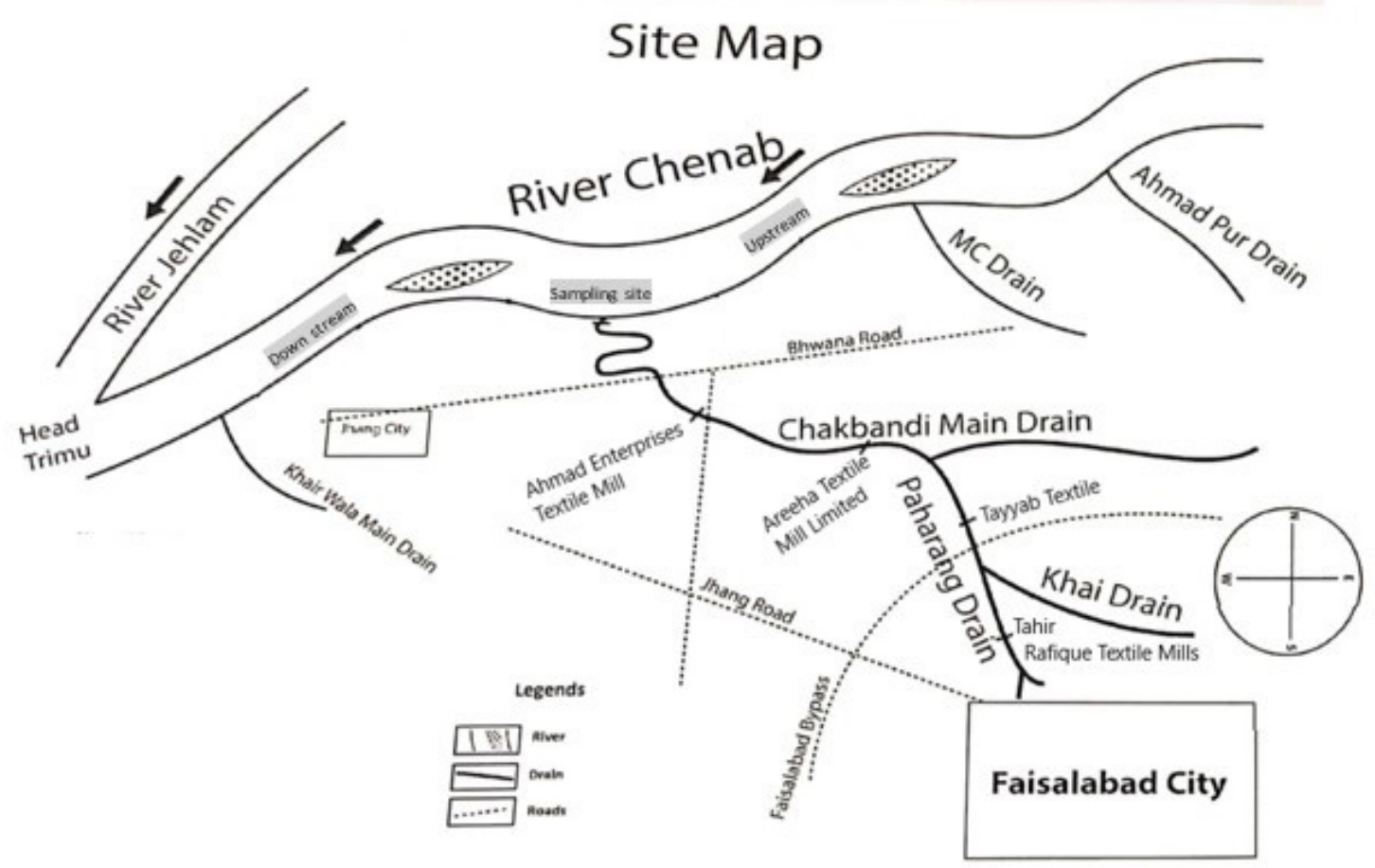

Figure 1. Site map of the study area showing different industries on the route of Chakbandi drain. 
Table 1. Physicochemical parameters observed in all treatments.

\begin{tabular}{|c|c|c|c|c|c|}
\hline Variable & Observations & Minimum & Maximum & Mean & Std. deviation \\
\hline T1 & \multirow{2}{*}{24} & \multirow{2}{*}{8.8} & \multirow{2}{*}{9.2} & \multirow{2}{*}{8.95} & \multirow{2}{*}{0.16} \\
\hline pH & & & & & \\
\hline Temperature & 24 & 18.62 & 33.60 & 14.71 & 9.40 \\
\hline DO & 24 & 4.3 & 9.90 & 6.38 & 1.18 \\
\hline $\mathrm{CO} 2$ & 24 & 0.0 & 0.0 & 0.00 & 0.00 \\
\hline Hardness & 24 & 210.0 & 350.0 & 239.57 & 47.75 \\
\hline Conductivity & 24 & 5.1 & 7.0 & 5.68 & 0.58 \\
\hline Salinity & 24 & 2.52 & 3.62 & 2.78 & 0.25 \\
\hline Alkalinity & 24 & 920.0 & 1385.0 & 1238.00 & 113.95 \\
\hline TDS & 24 & 3114.0 & 4309.0 & 3311.76 & 271.61 \\
\hline T2 & 24 & 9.01 & 10.1 & 9.75 & 0.19 \\
\hline \multicolumn{6}{|l|}{$\mathrm{pH}$} \\
\hline Temperature & 24 & 18.63 & 33.68 & 14.71 & 9.45 \\
\hline DO & 24 & 3.8 & 9.10 & 6.31 & 1.12 \\
\hline $\mathrm{CO} 2$ & 24 & 0.0 & 0.0 & 0.00 & 0.00 \\
\hline Hardness & 24 & 200.0 & 340.0 & 239.56 & 47.74 \\
\hline Conductivity & 24 & 5.6 & 7.2 & 5.69 & 0.66 \\
\hline Salinity & 24 & 2.54 & 3.64 & 2.80 & 0.28 \\
\hline Alkalinity & 24 & 921.0 & 1387.0 & 1248.00 & 114.96 \\
\hline TDS & 24 & 3116.0 & 4312.0 & 3315.76 & 273.62 \\
\hline T3 & 24 & 9.01 & 10.6 & 9.95 & 0.21 \\
\hline \multicolumn{6}{|l|}{$\mathrm{pH}$} \\
\hline Temperature & 24 & 18.64 & 34.68 & 15.61 & 9.85 \\
\hline DO & 24 & 3.1 & 8.10 & 5.31 & 1.01 \\
\hline $\mathrm{CO} 2$ & 24 & 0.0 & 0.0 & 0.00 & 0.00 \\
\hline Hardness & 24 & 190.0 & 330.0 & 231.46 & 47.73 \\
\hline Conductivity & 24 & 5.7 & 8.2 & 5.89 & 0.86 \\
\hline Salinity & 24 & 2.84 & 3.66 & 2.85 & 0.30 \\
\hline Alkalinity & 24 & 923.0 & 1397.0 & 1258.00 & 116.96 \\
\hline TDS & 24 & 3118.0 & 4314.0 & 3316.76 & 274.62 \\
\hline Control & 24 & 8.6 & 9.0 & 8.80 & 0.14 \\
\hline \multicolumn{6}{|l|}{$\mathrm{pH}$} \\
\hline Temperature & 24 & 8.6 & 33.5 & 14.61 & 9.30 \\
\hline DO & 24 & 4.5 & 10.5 & 6.48 & 1.22 \\
\hline $\mathrm{CO} 2$ & 24 & 0.0 & 0.0 & 0.00 & 0.00 \\
\hline Hardness & 24 & 210.0 & 360.0 & 249.58 & 51.76 \\
\hline Conductivity & 24 & 4.9 & 6.9 & 5.64 & 0.53 \\
\hline Salinity & 24 & 2.5 & 3.6 & 2.77 & 0.24 \\
\hline Alkalinity & 24 & 920.0 & 1380.0 & 1236.00 & 111.94 \\
\hline TDS & 24 & 3113.0 & 4300.0 & 3308.75 & 269.62 \\
\hline
\end{tabular}

hours was used to determine $\mathrm{LC}_{50}$. After determination of $\mathrm{LC}_{50}$, sub-lethal concentrations i.e., 1.5\% (T1), 3\% (T2) and $4.5 \%$ (T3) were applied to three fish species polyculture system in 40L aquaria in triplicates and water samples from upstream sites was used as control. The experiment in 12 aquaria for 120 days (Jun-2020 to Sep-2020). 


\subsection{Preparation of fish samples}

After treatment the muscle tissue specimens were collected and maintained at $0^{\circ} \mathrm{C}$ until further analysis. After washing with distilled water, the sample were chopped $(2-3 \mathrm{~cm})$ then oven dried at $65^{\circ} \mathrm{C}$ until a constant weight was reached. Afterwards, they were ground and filtered with $1 \mathrm{~mm}$ mesh size and stored in airtight containers, following the method described by Mahboob (2013).

\subsection{Fatty acid profiling}

After lipids extraction from pretreated samples with $\mathrm{n}$-Hexane at $65^{\circ} \mathrm{C}$ using Soxhlet extraction, they were esterified using methanolic sulphuric acid (Tocher 2003). Then gas chromatography was performed; sample volume $0.2 \mathrm{ul}, \mathrm{N}_{2}$ as carrier, $\mathrm{H}_{2}$, air 30,40 and $500 \mathrm{~mL} /$ min respectively (Column size $2 \mathrm{~m}$, stationary phase $10 \%$ Diethyl glycol succinate with diameter of $2 \mathrm{~mm}$. Column temperature was set at $190^{\circ} \mathrm{C}$, injection port temperature $200^{\circ} \mathrm{C}$ and detection port temperature $250^{\circ} \mathrm{C}$. The resulting chromatograms were compared with those of obtained for the standard (Pure mixture of Fatty acid methyl esters (FAMEs)) (Hedayatifard and Jamali 2008).

\subsection{Statistical analysis}

The mean, standard error and analyses of variance (ANOVA) were calculated using SPSS-10 for PC. The means were compared by using Duncan's Multiple Range test. Probability values of $\mathrm{P}<0.05$ were considered significant.

\section{Results and Discussions}

Table 2 shows saturated fatty acid profile of Labeo rohita (Ham.) were significantly higher in treatments as compared to controls moreover maximum value of saturated fatty acid were observed in T3 as compared to $\mathrm{T} 2$ and $\mathrm{T} 1$ respectively. Concentration of unsaturated fatty acids decrease gradually as we increase the concentration of textile effluents for shop maximum value of unsaturated fatty acids present in T1 and gradually declined as we increase the effluent concentration in T2 an T3 similar observations were seen for polyunsaturated fatty acids like Omega 3 and Omega 6 fatty acids.

Table 3 shows fatty acid profile of Cirrhinus mrigalae (Ham.) as can be seen in table to maximum concentration of saturated fatty acids were present in T3 and T2 and T1 and minimum concentration of saturated fatty acids can be seen in control for unsaturated fatty acids this trend was reversed and minimum concentration of unsaturated fatty acids was present in T3 and T2 and T1 while control samples showed maximum concentration of unsaturated fatty acids including Omega 3 and Omega 6 and other polyunsaturated fatty acids.

Table 4 represents fatty acid profile of Catla catla (Ham.) similar trend was observed that is maximum concentration of saturated fatty acids was seen with increasing effluent treatment and minimum concentration of saturated fatty acids were present in controls and for unsaturated fatty acids minimum concentration of unsaturated fatty acids were present in $\mathrm{T} 3$ and $\mathrm{T} 2$ and $\mathrm{T} 1$ and maximum concentration was present in control samples.

The findings of present suggests that the values of PUFA decreased while that of SFA were increased in samples as compared to controls (Table 2-4).

The metal and other compounds are reported to cause oxidative stress that could be the cause of oxidation of PUFAs hence the decline in their concentrations (Gabryelak et al., 2000). Findings in brown trout (Samlo trutta) support this

Table 2. Fatty acid profile (\% total fatty acid) of Labeo rohita (Ham.) of different treatments.

\begin{tabular}{|c|c|c|c|c|}
\hline \multirow{2}{*}{ Fatty acid } & \multicolumn{4}{|c|}{ Groups } \\
\hline & Control & T1 & T2 & T3 \\
\hline C14:0 (Myristic acid) & $1.80 \pm 0.18$ & $1.99 \pm 0.22$ & $2.20 \pm 0.29$ & $2.53 \pm 0.49$ \\
\hline C15:0 (Pentadecanoic acid) & $1.22 \pm 0.18$ & $1.70 \pm 0.15$ & $1.95 \pm 0.20$ & $2.20 \pm 0.29$ \\
\hline C16:0 (Palmitic acid)** & $66.03 c \pm 1.77$ & $70.42 c \pm 1.79$ & $92.03 c \pm 1.89$ & $122.42 \mathrm{c} \pm 1.95$ \\
\hline C17:0 (Heptadecanoic acid) & $0.69 \pm 0.08$ & $0.77 \pm 0.10$ & $0.9 \pm 0.12$ & $1.12 \pm 0.14$ \\
\hline C15:1 (Pentadecenoic acid)* & $1.40 \mathrm{~b} \pm 0.07$ & $1.35 b \pm 0.06$ & $1.27 \mathrm{~b} \pm 0.05$ & $1.19 b \pm 0.04$ \\
\hline C16:1n7 (Palmitoleic acid)* & $1.61 \mathrm{a} \pm 0.08$ & $1.53 a \pm 0.06$ & $1.35 \mathrm{a} \pm 0.04$ & $1.09 \mathrm{a} \pm 0.03$ \\
\hline C18:1n9 (Oleic acid)** & $5.90 \mathrm{~b} \pm 0.12$ & $5.75 b \pm 0.10$ & $5.55 b \pm 0.08$ & $5.30 \mathrm{~b} \pm 0.06$ \\
\hline C22:1n9 (Erucic acid) & $1.50 \pm 0.07$ & $1.39 \pm 0.05$ & $1.26 \pm 0.03$ & $1.03 \pm 0.02$ \\
\hline C18:2n6 (Linoleic acid) ${ }^{* *}$ & $4.04 \mathrm{~b} \pm 0.20$ & $3.86 b \pm 0.17$ & $3.49 b \pm 0.13$ & $2.99 \mathrm{~b} \pm 0.09$ \\
\hline C18:3n3 ( $\alpha$-Linolenic acid)* & $3.99 \mathrm{a} \pm 0.87$ & $3.62 \mathrm{a} \pm 0.77$ & $3.42 \mathrm{a} \pm 0.56$ & $3.04 \mathrm{a} \pm 0.30$ \\
\hline C20:3n6 (Eicosatrienoic acid) & $1.76 \pm 1.40$ & $1.36 \pm 1.20$ & $0.70 \pm 0.80$ & $0.50 \pm 0.70$ \\
\hline C20:5n3 (Eicosapentaenoic acid) & $1.29 \pm 0.14$ & $1.13 \pm 0.12$ & $0.99 \pm 0.09$ & $0.78 \pm 0.07$ \\
\hline$\Sigma \omega-3$ PUFA $^{*}$ & $5.80 \mathrm{a} \pm 0.38$ & $5.66 \mathrm{a} \pm 0.27$ & $5.20 \mathrm{a} \pm 0.18$ & $4.80 \mathrm{a} \pm 0.09$ \\
\hline$\Sigma \omega-6$ PUFA & $7.23 \pm 2.32$ & $6.93 \pm 2.18$ & $6.60 \pm 2.09$ & $6.35 \pm 1.99$ \\
\hline$\omega-3: \omega-6$ PUFA* & $0.86 a \pm 0.23$ & $0.71 \mathrm{a} \pm 0.19$ & $0.59 a \pm 0.15$ & $0.39 \mathrm{a} \pm 0.12$ \\
\hline
\end{tabular}

a,b,c,d Means bearing different superscripts in a row differ significantly. ${ }^{*} \mathrm{P}<0.05 ;{ }^{* *} \mathrm{P}<0.01$. ND: Not detected. 
Table 3. Fatty acid profile (\% total fatty acid) of Cirrhinus mrigalae (Ham.) of different Treatments.

\begin{tabular}{|c|c|c|c|c|}
\hline \multirow{2}{*}{ Fatty acid } & \multicolumn{4}{|c|}{ Group } \\
\hline & Control & T1 & T2 & T3 \\
\hline C14:0 (Myristic acid)* & $4.55 \mathrm{a} \pm 0.42$ & $4.65 a \pm 0.46$ & $4.76 a \pm 0.53$ & $4.91 \mathrm{a} \pm 0.61$ \\
\hline $\begin{array}{l}\text { C15:0 (Pentadecanoic } \\
\text { acid)** }\end{array}$ & $3.70 \mathrm{a} \pm 0.09$ & $3.85 \mathrm{a} \pm 0.13$ & $3.96 a \pm 0.15$ & $4.21 \mathrm{a} \pm 0.18$ \\
\hline C16:0 (Palmitic acid) ${ }^{* *}$ & $12.84 \mathrm{~b} \pm 0.69$ & $31.28 c \pm 0.61$ & $7.25 a \pm 0.07$ & $43.90 \mathrm{~d} \pm 0.74$ \\
\hline $\begin{array}{l}\text { C17:0 (Heptadecanoic } \\
\text { acid) }\end{array}$ & $1.88 \pm 0.04$ & $1.99 \pm 0.06$ & $2.13 \pm 0.08$ & $2.33 \pm 0.14$ \\
\hline C16:1n7 (Palmitoleic acid) & $3.88 \mathrm{~b} \pm 0.24$ & $3.71 \mathrm{~b} \pm 0.21$ & $3.55 \mathrm{~b} \pm 0.16$ & $3.20 \mathrm{~b} \pm 0.10$ \\
\hline C18:1n9c (Oleic acid) ${ }^{* *}$ & $42.12 \mathrm{c} \pm 0.56$ & $41.13 c \pm 0.43$ & $40.17 c \pm 0.20$ & $38.09 c \pm 0.08$ \\
\hline $\begin{array}{l}\text { C20:1n9 (Eicosenoic } \\
\text { acid) }{ }^{*}\end{array}$ & $2.73 b \pm 0.55$ & $2.41 \mathrm{~b} \pm 0.35$ & $2.02 \mathrm{~b} \pm 0.19$ & $1.74 b \pm 0.01$ \\
\hline C22:1n9 (Erucic acid)** & $1.88 \mathrm{~b} \pm 0.15$ & $1.40 \mathrm{~b} \pm 0.11$ & $1.02 \mathrm{~b} \pm 0.08$ & $0.87 \mathrm{~b} \pm 0.02$ \\
\hline C18:2n6 (Linoleic acid) ${ }^{* *}$ & $16.70 \mathrm{c} \pm 1.27$ & $16.02 \mathrm{c} \pm 1.24$ & $14.34 \mathrm{c} \pm 1.11$ & $12.14 \mathrm{c} \pm 1.03$ \\
\hline C18:3n3 (Linolenic acid) & $4.30 \pm 0.17$ & $4.01 \pm 0.14$ & $3.34 \pm 0.10$ & $2.26 \pm 0.01$ \\
\hline $\begin{array}{l}\text { C20:4n6 (Arachidonic } \\
\text { acid)** }\end{array}$ & $0.28 a \pm 0.13$ & $0.20 \mathrm{a} \pm 0.10$ & $0.11 \mathrm{a} \pm 0.09$ & $0.04 a \pm 0.01$ \\
\hline $\begin{array}{l}\text { C20:5n3 } \\
\text { (Eicosapentaenoic acid)* }\end{array}$ & $1.19 \mathrm{a} \pm 0.96$ & $1.07 a \pm 0.75$ & $0.89 a \pm 0.65$ & $0.20 \mathrm{a} \pm 0.45$ \\
\hline$\Sigma \omega-3$ PUFA $^{*}$ & $5.16 \mathrm{a} \pm 1.05$ & $4.56 \mathrm{a} \pm 0.80$ & $3.99 a \pm 0.60$ & $2.98 \mathrm{a} \pm 0.43$ \\
\hline$\Sigma \omega-6$ PUFA $^{* *}$ & $19.60 \mathrm{~b} \pm 2.08$ & $19.01 \mathrm{~b} \pm 1.60$ & $17.62 \mathrm{~b} \pm 1.09$ & $15.02 \mathrm{~b} \pm 0.20$ \\
\hline$\omega-3: \omega-6$ PUFA $^{* *}$ & $0.25 a \pm 0.03$ & $0.22 \mathrm{a} \pm 0.03$ & $0.219 a \pm 0.02$ & $0.15 a \pm 0.01$ \\
\hline
\end{tabular}

a,b,c,d Means bearing different superscripts in a row differ significantly. ${ }^{*} \mathrm{P}<0.05 ;{ }^{* *} \mathrm{P}<0.01$. ND: Not detected.

Table 4. Fatty acid profile (\% total fatty acid) of Catla catla (Ham.) of different Treatments.

\begin{tabular}{|c|c|c|c|c|}
\hline \multirow{2}{*}{ Fatty acids } & \multicolumn{4}{|c|}{ Groups } \\
\hline & Control & T1 & T2 & T3 \\
\hline C14:0 (Myristic acid)* & $3.49 \mathrm{a} \pm 0.23$ & $3.99 a \pm 0.37$ & $5.89 \mathrm{a} \pm 0.97$ & $7.38 \mathrm{a} \pm 1.21$ \\
\hline C15:0 (Pentadecanoic acid) & $2.24 \mathrm{~b} \pm 0.09$ & $2.86 \mathrm{~b} \pm 0.21$ & $3.96 \mathrm{~b} \pm 0.55$ & $4.67 \mathrm{~b} \pm 0.77$ \\
\hline C16:0 (Palmitic acid)** & $30.18 c \pm 0.51$ & $31.91 \mathrm{c} \pm 0.82$ & $33.11 \mathrm{c} \pm 1.14$ & $36.01 \mathrm{c} \pm 0.80$ \\
\hline C17:0 (Heptadecanoic acid) & $3.80 \pm 0.12$ & $4.60 \pm 0.09$ & $6.40 \pm 0.06$ & $8.90 \pm 0.03$ \\
\hline C16:1n7 (Palmitoleic acid)* & $1.48 \mathrm{a} \pm 0.17$ & $1.12 \mathrm{a} \pm 0.11$ & $0.78 a \pm 0.07$ & $0.23 a \pm 0.05$ \\
\hline C17:1n7 (Heptadecenoic acid) ${ }^{* *}$ & $1.16 a \pm 0.03$ & $1.06 a \pm 0.03$ & $0.86 a \pm 0.02$ & $0.50 \mathrm{a} \pm 0.01$ \\
\hline C18:1n9 (Oleic acid) ${ }^{* *}$ & $36.14 \mathrm{~b} \pm 0.73$ & $35.11 \mathrm{~b} \pm 0.59$ & $33.28 \mathrm{~b} \pm 0.37$ & $30.34 \mathrm{~b} \pm 0.17$ \\
\hline C18:2n6 (Linoleic acid)* & $5.97 \mathrm{~b} \pm 0.03$ & $5.03 \mathrm{~b} \pm 0.03$ & $4.71 b \pm 0.02$ & $4.01 \mathrm{~b} \pm 0.02$ \\
\hline C18:2n6t (Linolelaidic acid)* & $0.10 \mathrm{a} \pm 0.01$ & $0.08 a \pm 0.01$ & $0.06 a \pm 0.01$ & $0.04 \mathrm{a} \pm 0.01$ \\
\hline C18:3n3 (Linolenic acid) ${ }^{* *}$ & $7.12 \mathrm{a} \pm 0.11$ & $6.92 \mathrm{a} \pm 0.09$ & $5.62 \mathrm{a} \pm 0.07$ & $4.22 \mathrm{a} \pm 0.05$ \\
\hline C20:5n3 (Eicosapentaenoic acid)* & $2.47 a \pm 0.11$ & $2.08 \mathrm{a} \pm 0.09$ & $1.77 \mathrm{a} \pm 0.07$ & $1.31 \mathrm{a} \pm 0.06$ \\
\hline$\Sigma \omega-3$ PUFA $^{*}$ & $10.01 \mathrm{a} \pm 0.49$ & $9.23 a \pm 0.39$ & $8.16 a \pm 0.31$ & $6.60 \mathrm{a} \pm 0.23$ \\
\hline$\Sigma \omega-6$ PUFA* $^{*}$ & $1.23 a \pm 0.47$ & $1.04 a \pm 0.32$ & $0.84 a \pm 0.27$ & $0.34 a \pm 0.19$ \\
\hline$\omega-3: \omega-6$ PUFA & $9.22 \pm 3.11$ & $9.01 \pm 2.95$ & $8.04 \pm 2.34$ & $6.74 \pm 2.01$ \\
\hline
\end{tabular}

a,b,c,d Means bearing different superscripts in a row differ significantly. ${ }^{*} \mathrm{P}<0.05 ;{ }^{* *} \mathrm{P}<0.01$. ND: Not detected.

argument where the 30 days exposure to 10 and $20 \mathrm{mgL}^{-1}$ concentrations of glyphosate based herbicide Roundup ${ }^{\circledR}$ accelerated the oxidation of omega-3 HUFAs (Bayir et al., 2013). Similar observations were made about gilt-head sea bream Sparus aurata after exposure to a pesticide, Diuron, and in Asian sea-bass Lates calcarifer after exposure to triazine herbicides Irgarol 1051, with various levels of exposure (Sánchez-Muros et al., 2013; Ali et al., 2015). 
Similar changes were observed in the study of Hussain et al. (2015), where fatty acid profiles of fish species collected from polluted sites of Chenab river were negatively affected as compared to farmed fish.

The perturbed fatty acid profiles observed in present study are also in line with those found in Atlantic bluefin tuna after exposure by POPs. There was a positive correlation in levels of SFAs and PUFAs with the concentrations of dioxin-like polychlorinated biphenyls (DL-PCB). Moreover, the exposure to polychlorinated dibenzo-p-dioxins and dibenzofurans (PCDD/Fs), also caused disturbance in normal fatty acid profiles of the exposed animal. Another study in marine fishes also reported a positive correlation between the levels of two essential FAs (EPA and DHA) and amounts of POPs (Geng et al., 2015).

The oxidative stress caused by pollutants can also interfere with the enzymatic activities of those enzymes which are involved in maintenance of a balance between SFAs, MUFAs and PUFAs. As the activity of fatty acid synthase (FAS) were reported to be elevated after triazol pesticide Paclobutrazol (PBZ) treatment. Thus there was an increased level of SFAs and MUFAs was observed in rockfish Sebastiscus marmoratus (Sun et al., 2013).

\section{Conclusion}

Presence of different pollutants in water bodies are accumulated in fish tissues and they deteriorate different physiological processes in fish body as we found in present study fatty acid profiles are vulnerable to heavy metal or textile industry effluent pollution, so fish can be used as a good bio indicator to assess environmental pollution specifically textile industry pollution in water bodies.

\section{References}

ALI, H.R., ARIFFIN, M.M., SHEIKH, M.A., MOHAMED SHAZILI, N.A. and BACHOK, Z., 2015. Toxicological studies of Irgarol-1051 and its effects on fatty acid composition of Asian sea-bass, Lates calcarifer. Regional Studies in Marine Science, vol. 2, pp. 171-176. http://dx.doi.org/10.1016/j.rsma.2015.09.008.

BAYIR, M., SIRKECIOGLU, A.N., BAYIR, A. and ARAS, M., 2013. Alterations in fatty acids of polar lipids in Saltno trutta on longterm exposure to a glyphosate-based herbicide (roundup ${ }^{\circledR}$ ). Pakistan Journal of Biological Sciences, vol. 16, no. 20, pp. 1194-1198. http://dx.doi.org/10.3923/pjbs.2013.1194.1198. PMid:24506022.

CHAUDHRY, A.S. and JABEEN, F., 2011. Assessing metal, protein, and DNA profiles in Labeo rohita from the Indus River in Mianwali, Pakistan. Environmental Monitoring and Assessment, vol. 174, no. 1-4, pp. 665-679. http://dx.doi.org/10.1007/s10661-010-1486-4.

ENSINK, J.H.J., MAHMOOD, T., VAN DER HOEK, W., RASCHID-SALLY, L. and AMERASINGHE, F.P., 2004. A nationwide assessment of wastewater use in Pakistan: an obscure activity or a vitally important one? Water Policy, vol. 6, no. 3, pp. 197-206. http:// dx.doi.org/10.2166/wp.2004.0013.

GABRYELAK, T., FILIPIAK, A. and BRICHON, G., 2000. Effects of zinc on lipids of erythrocytes from carp (Cyprinus carpio L.) acclimated to different temperatures. Comparative Biochemistry and Physiology. Part C, Pharmacology, Toxicology E'Endocrinology, vol. 127, no. 3, pp. 335-343. http://dx.doi.org/10.1016/S07428413(00)00161-4. PMid:11246505.

GENG, J.J., LI, H., LIU, J.P., YANG, Y., JIN, Z.L., ZHANG, Y.N., ZHANG, M.L., CHEN, L.Q. and DU, Z.Y., 2015. Nutrients and contaminants in tissues of five fish species obtained from Shanghai markets: risk-benefit evaluation from human health perspectives. The Science of the Total Environment, vol. 536, pp. 933-945. http:// dx.doi.org/10.1016/j.scitotenv.2015.06.057. PMid:26105705.

HEDAYATIFARD, M. and JAMALI, Z., 2008. Evaluation of omega-3 fatty acids composition in Caspian Sea pike perch (Sander lucioperca L.). International Journal of Agriculture and Biology, vol. 10, pp. 235-237.

HUSSAIN, B., SULTANA, T., SULTANA, S., AHMED, Z. and MAHBOOB, S., 2018. Study on impact of habitat degradation on proximate composition and amino acid profile of Indian major carps from different habitats. Saudi Journal of Biological Sciences, vol. 25, no. 4, pp. 755-759. http://dx.doi.org/10.1016/j.sjbs.2018.02.004. PMid:29740241.

HUSSAIN, K., RAHMAN, M., PRAKASH, A. and HOQUE, R.R., 2015. Street dust bound PAHs, carbon and heavy metals in Guwahati city: seasonality, toxicity and sources. Sustainable Cities and Society, vol. 19, pp. 17-25. http://dx.doi.org/10.1016/j. scs.2015.07.010.

LUND, L.H., EDWARDS, L.B., KUCHERYAVAYA, A.Y., DIPCHAND, A.I., BENDEN, C., CHRISTIE, J.D., DOBBELS, F., KIRK, R., RAHMEL, A.O., YUSEN, R.D. and STEHLIK, J., 2013. The registry of the international society for heart and lung transplantation: Thirtieth official adult heart transplant report - 2013; Focus theme: age. The Journal of Heart and Lung Transplantation, vol. 32, no. 10, pp. 951-964. http://dx.doi.org/10.1016/j. healun.2013.08.006. PMid:24054804.

LV, Y.Z., YAO, L., WANG, L., LIU, W.R., ZHAO, J.L., HE, L.Y. and YING, G.G., 2019. Bioaccumulation, metabolism, and risk assessment of phenolic endocrine disrupting chemicals in specific tissues of wild fish. Chemosphere, vol. 226, pp. 607-615. http://dx.doi. org/10.1016/j.chemosphere.2019.03.187. PMid:30954895.

MAHBOOB, T., 2013. Serum calcium, magnesium and parathyroid hormone in normal pregnant and pre-eclamptic women in Karachi, Pakistan. Journal of Hypertension : Open Access, vol. 03, no. 02. http://dx.doi.org/10.4172/2167-1095.1000143.

RHEE, J.J., KIM, E., BURING, J.E. and KURTH, T., 2017. Fish consumption, omega-3 fatty acids, and risk of cardiovascular disease. American Journal of Preventive Medicine, vol. 52, no. 1, pp. 10-19. http:// dx.doi.org/10.1016/j.amepre.2016.07.020. PMid:27646568.

SÁNCHEZ-MUROS, M.J., VILLACRECES, S., MIRANDA-DE LA LAMA, G., DE HARO, C. and GARCÍA-BARROSO, F., 2013. Effects of chemical and handling exposure on fatty acids, oxidative stress and morphological welfare indicators in gilt-head sea bream (Sparus aurata). Fish Physiology and Biochemistry, vol. 39, no. 3, pp. 581-591. http://dx.doi.org/10.1007/s10695-012-9721-2. PMid:23010939.

SUN, L., LI, J., ZUO, Z., CHEN, M. and WANG, C., 2013. Chronic exposure to paclobutrazol causes hepatic steatosis in male rockfish Sebastiscus marmoratus and the mechanism involved. Aquatic Toxicology, vol. 126, pp. 148-153. http://dx.doi.org/10.1016/j. aquatox.2012.11.002. PMid:23202249.

TARIQ, M., ANAYAT, A., WASEEM, M., RASOOL, M.H., ZAHOOR, M.A., ALI, S., RIZWAN, M., ABDEL-DAIM, M.M. and ALKAHTANI, S., 2020. Physicochemical and bacteriological characterization of industrial wastewater being discharged to surface water bodies: significant threat to environmental pollution and human health. Journal of Chemistry, vol. 2020, pp. 1-10. http:// dx.doi.org/10.1155/2020/9067436.

TOCHER, D.R., 2003. Metabolism and functions of lipids and fatty acids in teleost fish. Reviews in Fisheries Science, vol. 11, no. 2, pp. 107-184. http://dx.doi.org/10.1080/713610925. 